\title{
COL1A2 Gene
}

National Cancer Institute

\section{Source}

National Cancer Institute. COL1A2 Gene. NCI Thesaurus. Code C29950.

This gene plays a role in the compositional regulation of several connective tissues. 